Disclosure of Interests: None declared

DOI: 10.1136/annrheumdis-2019-eular.2139

\section{AB0293 ASSOCIATION OF HOMOCYSTEINE WITH BONE MINERAL DENSITY IN RHEUMATOID ARTHRITIS PATIENTS}

Antonio Alvarez de Cienfuegos ${ }^{1}$, Lucia Cantero-Nieto ${ }^{2}$, José Alberto GarcíaGómez $^{3}$, Jose Luis Callejas-Rubio ${ }^{4}$, Miguel A. González-Gay ${ }^{5}$, Norberto Ortego ${ }^{4}$ ${ }^{1}$ Vega Baja Hospital, Rheumatology, Orihuela, Spain; ${ }^{2}$ Santa Ana Hospital, Granada, Spain; ${ }^{3}$ Hospital General Universitari d'Elx, Elche, Spain; ${ }^{4}$ Hospital Universitario San Cecilio, Unit of Systemic Autoimmune Diseases-Internal Medicine, Granada, Spain; ${ }^{5}$ IDIVAL, Santander, Spain

Background: Rheumatoid arthritis (RA) is a chronic inflammatory autoimmune disease with unknown etiology that primarily affects the peripheral joints and, over time, leads to loss of mobility if untreated. RA is an important risk factor of osteoporosis and occurrence of fractures. Many authors describe a significantly higher frequency of osteoporosis and fractures in patients with RA in comparison to a control group. The aetiology of progressive bone mass loss in RA patients is multi-factorial and remains obscure. Factors related to the pathological process - activity of RA and applied therapy - seem to be significant. Homocysteine (Hcy) is a sulfhydryl containing amino acid produced by demethylation of an essential amino acid (methionine). A high serum level of Hcy has been recently recognized as a risk factor for osteoporosis and osteoporotic fractures in postmenopausal women.

Objectives: The purpose of this study was to evaluate serum Hcy levels in RA patients compared with healthy controls, examine possible associations between Hcy and bone mineral density.

Methods: This cross-sectional study was performed in Vega-Baja Hospital, Orihuela (Spain) from November 2016 to May 2018. We prospectively enrolled 63 consecutive women patients affected by RA and followed at the Vega-Baja Hospital (Orihuela, Spain) and 60 matched healthy women controls. All patients included in this study had normal serum creatinine (Cr) levels and met the 2010 American College of Rheumatology/European League Against Rheumatism (ACR/EULAR) criteria for RA. Serum Hcy was analyzed using immunonephelometric method. Bone mineral density (BMD) of femoral neck and lumbar spine was measured by dualenergy X-ray absorptiometry (DXA).

Results: A total of 63 female patients were included in our study, with a mean (SD) age of $53 \pm 8$ years. The majority were Caucasian (90.5\%) Thirty-four patients were menopausal and twenty-nine non-menopausal patients. The mean duration of RA was $8.5 \pm 5.8$ years. The mean disease activity scores in 28 joints (DAS28) according to the erythrocyte sedimentation rate (ESR) indicated low disease activity $3.0 \pm 1.3$. The mean health assessment questionnaire (HAQ) was $0.75 \pm 0.67$. Twentyeight patients were treated with methotrexate, with a median weekly dose of $11.5 \pm 4.8 \mathrm{mg}$, all the patients received $10 \mathrm{mg}$ folic acid supplementation per week. Serum Hcy concentrations were significantly higher in the RA patients than those in the control group: $[9.93$ (5.6-18.8) vs. 7.11 (4.9-11.1), $\mathrm{pg} / \mathrm{mL} ; P<0.001]$. Serum levels of Hcy were inversely related to lumbar spine BMD and femur neck BMD ( $r-0.28 ; P<0.05)$

Conclusion: Patients with RA have high levels of Hcy that correlate, inversely, with bone mass suggesting that hyperhomocysteinemia is a risk factor for osteoporosis in patients with RA.

\section{REFERENCES}

[1] Kim SY, Schneeweiss S, Liu J, Daniel GW, Chang CL, Garneau K, Solomon $\mathrm{DH}$. Risk of osteoporotic fracture in a large population-based cohort of patients with rheumatoid arthritis. Arthritis Res Ther. 2010; 12: 154-164.

[2] Macovei L, Ancuta C, Belibou C, Chirieac R. Bone mineral density in patients with rheumatoid arthritis. Rev Med Chir Soc Med Nat lasi. 2011; 115 (3): 723-730.

[3] Gjesdal CG, Vollset SE, Ueland PM, Refsum H, Drevon CA, Gjessing HK, Tell GS. Plasma total homocysteine level and bone mineral density: the Hordaland Homocysteine Study. Arch Intern Med. 2006; 166:88-94.

[4] Bucciarelli P, Martini G, Martinelli I, et al. The relationship between plasma homocysteine levels and bone mineral density in post-menopausal women. Eur J Intern Med. 2010; 21:301-305

Disclosure of Interests: Antonio Alvarez de Cienfuegos : None declared, Lucia Cantero-Nieto: None declared, José Alberto García-Gómez: None declared, Jose Luis Callejas-Rubio: None declared, Miguel A GonzálezGay Grant/research support from: Prof. MA Gonzalez-Gay received grants/ research supports from Abbvie, MSD, Jansen and Roche., Speakers bureau: Consultation fees/participation in company sponsored speaker's bureau from Pfizer, Lilly, Sobi, Celgene, Novartis, Roche and Sanofi., Norberto Ortego: None declared DOI: 10.1136/annrheumdis-2019-eular.7572

\section{AB0294 THE EFFECT OF SMOKING ON ENDOTHELIN-1 IN PATIENTS WITH RHEUMATOID ARTHRITIS}

Antonio Alvarez de Cienfuegos ${ }^{1}$, Lucia Cantero-Nieto ${ }^{2}$, José Alberto GarcíaGómez $^{3}$, Gema Robledo ${ }^{4}$, Javier Martin lbanez ${ }^{4}$, Raquel Ríos Fernández ${ }^{5}$, Miguel A. González-Gay 6 , Norberto Ortego ${ }^{5} .{ }^{1}$ Vega Baja Hospital, Rheumatology, Orihuela, Spain; ${ }^{2}$ Santa Ana Hospital, Granada, Spain; ${ }^{3}$ Hospital General Universitari d'Elx, Elche, Spain; ${ }^{4}$ Institute of Parasitology and Biomedicine LópezNeyra, IPBLN-CSIC, Granada, Spain; ${ }^{5}$ Hospital Universitario San Cecilio, Unit of Systemic Autoimmune Diseases-Internal Medicine, Granada, Spain; ${ }^{6} I D I V A L$, Santander, Spain

Background: Rheumatoid Arthritis (RA) is one of the chronic autoimmune diseases with an estimated prevalence of 1 to 2 percent of the tota population in the world. RA patients have an increased risk of morbidity and mortality from cardiovascular (CV) events as a result of accelerated atherosclerosis. Endothelin-1 (ET-1) is a hormone with strong vasoconstrictor properties, secreted in excessive amounts by damaged endothelial cells. However, the effect of this hormone depends on the presence of specific ET-1 receptors as well as their density and location. ET-1 is a mediator-activating autocrine and paracrine, primarily in the circulatory system. It induces the production of proinflammatory cytokines, exacerbating the inflammatory process.

Objectives: The objectives of this study were: to compare serum ET-1 levels between $R A$ patients and healthy controls and observe the relationship between tobacco smoking and serum levels of ET-1 in RA patients. Methods: This cross-sectional study was performed in Vega-Baja Hospital, Orihuela (Spain) from November 2016 to May 2018. We prospectively enrolled 63 consecutive women patients affected by RA and followed at the Vega-Baja Hospital (Orihuela, Spain) and 65 matched healthy women controls. All patients included in this study had normal serum creatinine (Cr) levels and met the 2010 American College of Rheumatology/European League Against Rheumatism (ACR/EULAR) criteria for RA. Current smokers were defined as those who reported having smoked $>1$ cigarette per day regularly during the year preceding the examination. Serum ET-1 was analyzed using ELISA.

Results: A total of 63 female patients were included in our study, with a mean (SD) age of $53 \pm 8$ years. The majority were Caucasian (90.5\%) The mean duration of RA was $8.5 \pm 5.8$ years. The mean disease activity scores in 28 joints (DAS28) according to the erythrocyte sedimentation rate (ESR) indicated low disease activity $3.0 \pm 1.3$. The mean health assessment questionnaire (HAQ) was $0.75 \pm 0.67$. Fourteen $(22 \%)$ patients had a smoking history. Serum ET-1 concentrations were significantly higher in the RA patients than those in the control group: [30.6 (0-50) vs. $21.7(0-50), \mathrm{pg} / \mathrm{mL} ; \quad P<0.001]$. Higher plasma ET-1 concentrations were significantly associated with smoking ( $r$ 0.29; $p<0.05)$.

Conclusion: Our data shows a significant difference in the concentration of serum ET-1 between RA patients and controls. We report significant positive association between serum levels of ET-1 and smoking status.

\section{REFERENCES}

[1] Gibofsky A. Overview of epidemiology, pathophysiology, and diagnosis of rheumatoid arthritis. Am J Manag Care. 2012; 18(13): S295-302.

[2] Castañeda S, Nurmohamed MT, González-Gay MA. Cardiovascular disease in inflammatory rheumatic diseases. Best Pract Res Clin Rheumatol. 2016; 30(5):851-869.

[3] Kowalczyk A, Kleniewska P, Kolodziejczyk M, Skibska B, Goraca A. The Role of Endothelin-1 and Endothelin Receptor Antagonists in Inflammatory Response and Sepsis. Arch. Immunol. Ther. Exp. 2015; 63:41-52.

[4] Mayes MD. Endothelin and endothelin receptor antagonists in systemic rheumatic disease. Arthritis Rheum. 2003; 48: 1190-1199.

Disclosure of Interests: Antonio Alvarez de Cienfuegos : None declared, Lucia Cantero-Nieto: None declared, José Alberto García-Gómez: None declared, Gema Robledo: None declared, Javier Martin lbanez: None declared, Raquel Ríos Fernández: None declared, Miguel A González-Gay Grant/research support from: Prof. MA Gonzalez-Gay received grants/ research supports from Abbvie, MSD, Jansen and Roche., Speakers bureau: Consultation fees/participation in company sponsored speaker's bureau from Pfizer, Lilly, Sobi, Celgene, Novartis, Roche and Sanofi., Norberto Ortego: None declared

DOI: 10.1136/annrheumdis-2019-eular.7766 